\title{
Prelacrimal Recess Approach for Maxillary Sinus Inverted Papilloma: Preliminary Study
}

\author{
Myung Jun Lee, Jae Mahn Cho, Byung Whoo Park, and Yong Wan Kim \\ Department of Otorhinolaryngology, Inje University Haeundae Paik Hospital, Busan, Korea
}

\author{
상악동 기원의 반전성 유두종 환자에서 전누골와 접근법: 예비연구 \\ 이명준 · 조재만 · 박병후 · 김용완 \\ 인제대학교 해운대백병원 이비인후과
}

Received September 8, 2018

Revised November 14, 2018

Accepted November 19, 2018

Address for correspondence

Yong Wan Kim, MD, PhD

Department of Otorhinolaryngology, Inje University

Haeundae Paik Hospital, 875 Haeun-daero, Haeundae-gu, Busan 48108, Korea

Tel $+82-51-797-2290$

Fax $+82-51-797-2304$

E-mail kimyw@paik.ac.kr
Background and Objectives Various surgical approaches have been employed for the complete resection of inverted papilloma (IP) of the nose and paranasal sinus. Sacrificing the inferior turbinate (IT) and nasolacrimal duct (NLD) is often unavoidable due to the anatomy of maxillary sinus. However, the prelacrimal recess approach (PLRA) provides a wider entrance to the maxillary sinus without the ablation of NLD and IT. We present seven cases of IP successfully treated by the PLRA.

Subjects and Method We collected data from seven different cases involving patients who underwent resection of IP by means of the PLRA from 2016 to 2017. If the lesion could not be removed first via middle meatal antrostomy (MMA), then PLRA was attempted. The surgical specimens were all confirmed to be IP.

Results Preoperative imaging studies demonstrated that the lesions of IP were located mainly in the maxillary sinus. All of the seven patients had unilateral lesions and all tumors were completely resected via PLRA. The follow-up ranged from 3 to 24 months, during which no recurrence or complications were observed in any of the seven patients.

Conclusion PLRA provides an adequate operation field without unfavorable scars. It allows the preservation of sinus structure and function. PLRA is feasible and can be used for the diffuse maxillary sinus IP. Korean J Otorhinolaryngol-Head Neck Surg 2019;62(5):284-7

Key Words Inverted papilloma · Minimally invasive surgical procedure.

\section{서 론}

반전성 유두종은 비부비동에 발생하는 종양 중 양성 종양 에 해당되며 치료 후 재발률이 높으며, 드물게 악성으로 전환 하는 특징을 보인다. 치료는 침습적인 광범위 근치술이 선호 되었으나 최근에는 비내시경하에 절제술이 표준이 되었다. ${ }^{1)}$

상악동에서 기원된 반전성 유두종의 경우 중비도 상악동 개방술, Caldwell-Luc 수술, 하비도 상악동 개방술, 내시경적

This is an Open Access article distributed under the terms of the Creative Commons Attribution Non-Commercial License (https://creativecommons.org/licenses/by-nc/4.0) which permits unrestricted non-commercial use, distribution, and reproduction in any medium, provided the original work is properly cited.
상악동 내측절제술 등 다양한 접근법이 알려져 있으며 내시 경적 상악동 내측절제술은 상악동의 전내측벽 및 전벽 기원 의 병변을 접근할 때에도 충분한 시야를 제공할 수 있다. 하 지만 일반적으로 코눈물관과 하비갑개가 제거되기 때문에 비 강 내 공기 유동에 변화를 주고 유루증을 유발할 수 있다. ${ }^{2)}$

이러한 단점을 보완하고자 상악동 수술법으로 내시경하 전누골와 접근법이 새롭게 고안되었고 이는 코눈물관과 하 비갑개의 손상없이 상악동의 병변을 잘 노출시킬 수 있다. ${ }^{3)}$

저자들은 상악동에서 기원한 반전성 유두종으로 진단된 7 명의 환자들을 전누골와 접근법과 중비도 상악동 개방술을 함께 활용하여 특별한 합병증 없이 병변을 완전히 제거하는 
데 성공하였기에 보고하는 바이다.

\section{대상 및 방법}

\section{대 상}

후향적 연구로 2016년 1월부터 2017년 12월까지 수술 전 비 내시경 및 영상학적 검사에서 반전성 유두종이 의심되는 환 자를 대상으로 연구되었다. 주병변이 상악동의 전벽에 위치 하여 술중에 중비도 상악동 개방술만으로 완전히 제거가 불 가능한 경우나 중비도 상악동 개방술만으로 제거를 하여도 정확한 확인이 필요한 7 명의 환자들에서 전누골와 접근법을
함께 시행하였다(Fig. 1). 이전에 비부비동 수술을 받았던 환 자는 없었다. 모두 일측성 병변이었으며 조직학적으로 반전성 유두종으로 확진 되었다. 본 연구는 인제대학교 해운대백병원 기관생명윤리위원회(IRB)의 연구승인(승인번호: 2018-09008-002)을 받았다.

\section{수술방법}

전신마취하 환측 비강을 관찰하여 우선적으로 중비도 상 악동 개방술을 시행하였으며 상악동 내에 가득차 있는 종물 을 확인하였다. 동결절편검사를 통해 반전성 유두종 소견을 얻었으며 관찰 가능한 범위 내에서 종물을 제거하였다. 전누
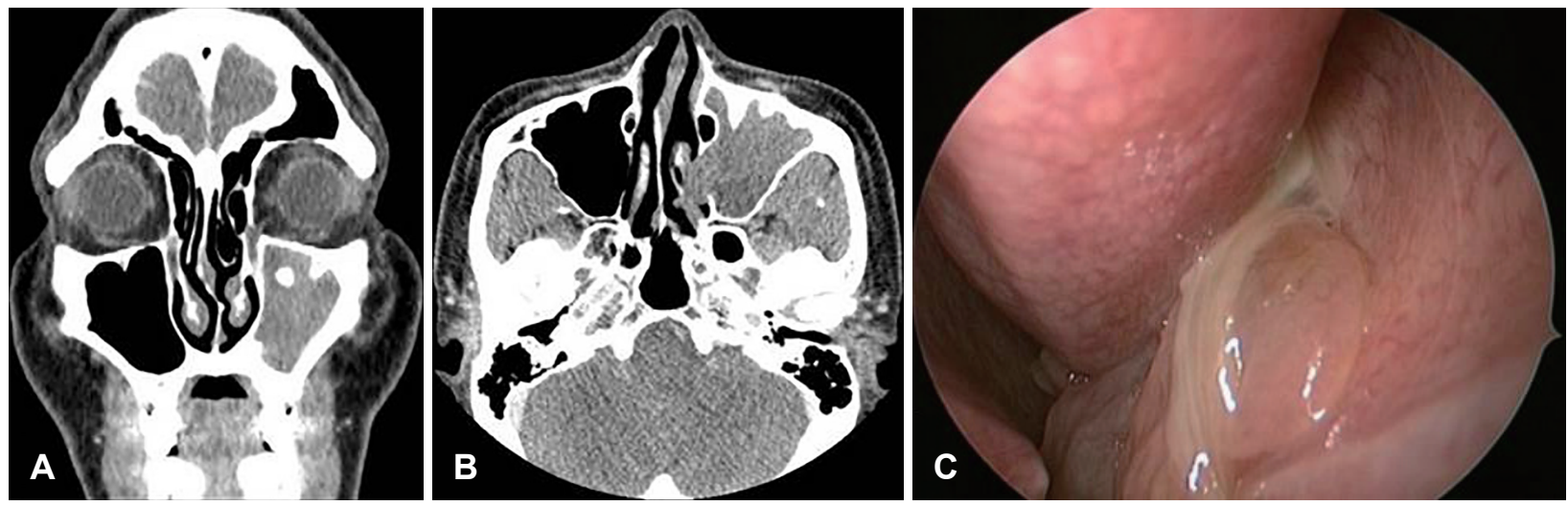

Fig. 1. Preoperative CT scans showing a soft tissue density extending from the left maxillary sinus through ostium into the nasal cavity and large osteophytic lesion in anterior aspect of left maxillary sinus (A and B). Nasal endoscopy - inverted papilloma extruding from the middle meatus $(C)$.

Fig. 2. Incision of the anterior end of inferior turbinate and the nasal mucosa is elevated from the lateral nasal wall (A). Resection of the lateral nasal wall by diamond burr (B). Inverted papilloma of anterior and inferior wall of the maxillary sinus is visible (C). Endoscopic view inside of the maxillary sinus after removal of inverted papilloma originating from the inferior wall of maxillary sinus (D).
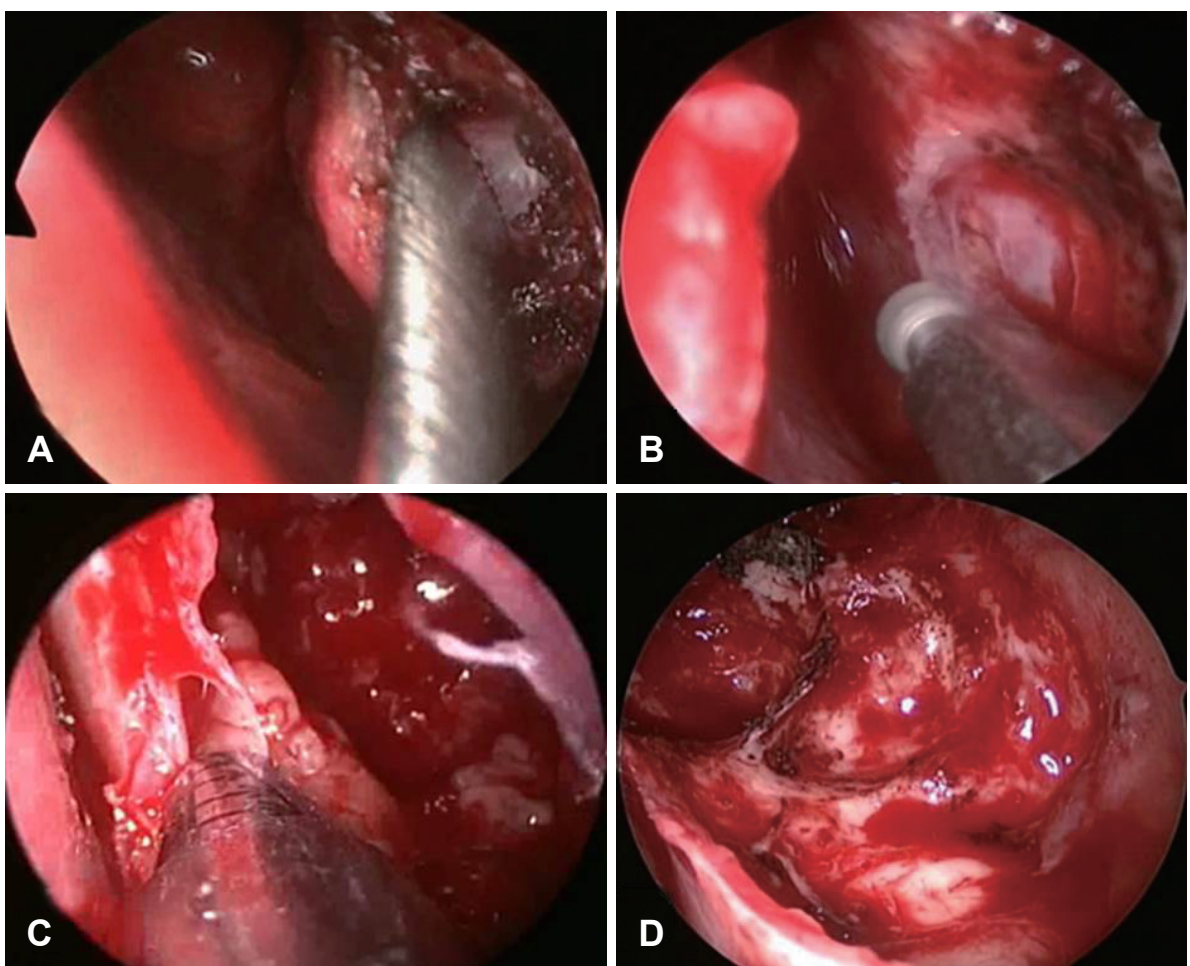
골와 접근법을 통하여 나머지 병변들을 남김없이 제거하기로 계획하였다. 먼저 하비갑개의 전부착부에서 수직 절개를 가 한 후, 하비갑개 및 하비도 외측 벽의 점막을 분리하였다. 다 이아몬드 버를 이용하여 하비갑개의 골부를 드릴하였고 하 비도 외측벽을 제거 후 미세흡입절삭기를 통하여 상악동내 로 접근하였다. 수술 중 코눈물관을 확인하고 보존하였다. 하 비갑개의 점막은 봉합사를 통하여 비중격에 고정하였으며 수술 후에 봉합사를 제거하고 하비갑개의 점막을 원위치 시 켰다. 큐렛, 보비, 미세흡입절삭기, 드릴 등을 이용하여 상악 동내 병변의 부착부위를 모두 제거하였으며 동결절편 검사 를 통하여 남은 병변이 없음을 확인하였다(Fig. 2).

\section{결 과}

7명의 환자 모두 상악동 내에서 기원한 반전성 유두종으로 확진 되었고 평균 연령은 56.4세(29 70세), 평균 추적 관찰 기간은 11 개월(3 24개월)이었다. 비강 및 상악동내에 국한되 어 다른 부비동으로의 침범은 없었고 Krouse's 병기 구분에 따라 4명은 $\mathrm{T} 3,3$ 명은 T2에 해당되었고 조직학적으로 악성 변화를 동반한 경우는 없었다(Table 1). 중비도 상악동 개방 술로 병변의 완전한 제거가 불충분한 경우 전누골와 접근법 을 시행하였다. 추적 관찰 기간 내에 비내시경상 육아 조직이 보이는 경우 조직검사를 시행하였으며 현재까지 환자들에서 는 $30^{\circ}, 70^{\circ}$ 비내시경상 재발이 의심되는 환자는 발견되지 않
아 영상학적 검사는 시행하지 않았다. 수술 후 코막힘, 유루 증, 윗입술 주변의 감각저하, 지속적인 코 안의 건조감 등의 합 병증은 발생하지 않았으며 2개월 이내에 회복된 하비갑개의 점막을 확인할 수 있었다(Fig. 3).

\section{고 찰}

비강 및 부비동에 발생하는 반전성 유두종에 대한 치료는 대부분 수술적 처치로 가능하나 완전한 절제가 이루어지지 않는다면 재발 가능성이 높다. 특히 상악동과 전두동에 위치 한 반전성 유두종은 다른 부비동에 발생한 경우보다 재발률 이 더 높다고 보고된 바 있다. ${ }^{4)}$ 상악동내 병변의 경계를 명확 하게 판단하기 힘든 경우 넓은 시야를 얻기 위해서 Caldwell $\mathrm{Luc}$ 수술, 측비절개술, 안면중앙부노출술 등의 비외적 접근 법이 시도 되었다. 이러한 술식들은 침습적이며 미용적인 측 면에서 단점이 존재하여 최근에는 내시경을 통한 수술법이 표준이 되었다. ${ }^{5}$

반전성 유두종이 상악동의 전내측과 하벽을 침범한 경우 는 내시경적 수술에 어려움이 발생하였지만 내시경적 상악동 내측절제술이 고안되면서 충분한 시야 및 공간을 확보할 수 있었다. ${ }^{6}$

하지만 내시경적 상악동 내측절제술은 코눈물관과 하비갑 개를 절제해야 하므로 합병증이 동반된다. 코눈물관 손상으 로 인한 유루증, 하비갑개의 절제로 인한 코막힘, 코 안의 건

Table 1. Characteristics of patients with inverted papilloma

\begin{tabular}{ccclcc}
\hline No. & Age $(\mathrm{yr})$ & Gender & \multicolumn{1}{c}{ Origin } & Stage & Current status \\
\hline 1 & 63 & $F$ & Infraorbital canal & T3 & Disease free \\
2 & 53 & $M$ & Anterior wall & T3 & Disease free \\
3 & 29 & F & Inferior wall & T3 & Disease free \\
4 & 62 & $M$ & Anterior wall & T3 & Disease free \\
5 & 70 & $M$ & Superior wall & T2 & Disease free \\
6 & 50 & M & Medial wall & T2 & Disease free \\
7 & 68 & F & Medial and superior wall & T2 & Disease free \\
\hline
\end{tabular}

Fig. 3. Postoperative endoscopic view shows the preservation of the inferior turbinate 2 months after surgery (A). The anterior wall of the maxillary sinus is clear $(B)$.
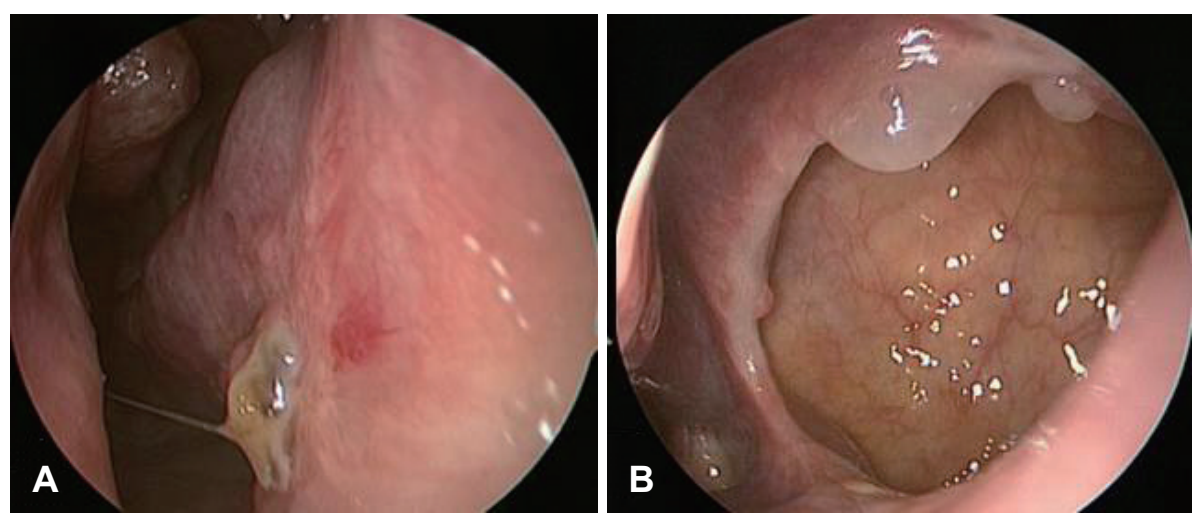
조감, 안면통증 등의 빈 코 증후군(empty nose syndrome)이 발생할 수 있다. 이를 보완하고자 비강내 구조물을 보존하면 서 상악동 및 상악의 골부의 병변을 제거할 수 있는 전누골 와 접근법이 제시되었다. ${ }^{7-9)}$ 본 연구에서도 중비도 상악동 개 방술을 통하여 반전성 유두종의 완전한 제거가 힘든 환자들 을 대상으로 전누골와 접근법을 함께 시행하였다. 수술 중 하비갑개의 절제 없이도 상악동 내 공간을 모두 확인할 수 있 었으며 기구 조작에도 충분한 공간이 확보되었다. 하비갑개 를 보존하였으나 3 명의 환자들이 수술 후 치통 및 코 안의 건 조감을 호소하였다. 하지만 2 개월 이내에 하비갑개의 절개 부 위의 점막이 완전히 회복되어 증상들이 호전되었다. 1 명의 환 자는 수술 후 입원 기간 중 코를 푼 뒤에 안와부 부종이 발 생하였으나 수일 뒤 회복되었다. 이외 주요 합병증은 발생하 지 않았으며 추적 관찰 기간 동안 재발의 소견은 없었다.

전누골와 접근법은 익구개와, 측두하와 등에 위치한 병변 의 제거에도 적용될 수 있으며 비강내 기능을 보존함과 동시 에 충분한 수술 시야를 제공한다는 점에서 유용하다. ${ }^{10)}$ 또한 방사선 치료와 전누골와 접근법을 통한 병변의 제거를 병행 하여 상악동에 발생한 초기 악성 신생물의 치료에도 활용될 수 있다. ${ }^{11)}$

상악동 기원의 반전성 유두종의 수술에 있어서 전누골와 접근법과 다른 수술법들의 치료 성적과 재발에 대한 비교가 명확히 이루지지 않았으나 본 연구와 문헌들에서 치명적인 합병증이나 높은 재발률이 보고된 바는 없었다. 최근에는 하 비갑개를 보존하는 내시경적 상악동 내측절제술도 시행되고 있으며 추적관찰 시 비내시경만으로도 상악동 관찰이 용이하 다. 하지만 비강의 외측벽을 희생해야 하는 경우가 생기므로 전누골와 접근법이 비강생리적으로 보존적인 방법이다. 또한 내시경적 상악동 내측절제술 시 종물이 상악동의 하부 혹은 전벽에 불규칙하게 존재하면 제거에 어려움이 있을 수 있다. ${ }^{12)}$ 반전성 유두종의 부착부가 상악동 내측일 경우 재발률이 가 장 높다고 보고된 바 있는데 전누골와 접근법은 병변의 부착 부위에 관계없이 완전한 절제가 가능하다. 하지만 전누골와 접근법시 절개부위가 콧구멍에 가깝거나 상악동 기저부에 과도한 조작시에 콧구멍의 변형이나 입 주위의 감각저하가 발생 할 수 있다. ${ }^{13,14)}$ 이러한 단점들이 보완되기 위하여 상악 동내 반전성 유두종이 미만성으로 존재하는 환자에게 전누 골와 접근법을 적극 활용하여 많은 증례들이 보고되어야 할
것으로 사료된다.

\section{ORCID}

Yong Wan Kim ～https://orcid.org/0000-0002-6010-312X

\section{REFERENCES}

1) Philpott CM, Dharamsi A, Witheford M, Javer AR. Endoscopic management of inverted papillomas: Long-term results--the St. Paul's Sinus Centre experience. Rhinology 2010;48(3):358-63.

2) Chen XB, Lee HP, Chong VF, Wang de Y. Numerical simulation of the effects of inferior turbinate surgery on nasal airway heating capacity. Am J Rhinol Allergy 2010;24(5):e118-22.

3) Nakayama T, Asaka D, Okushi T, Yoshikawa M, Moriyama H, Otori N. Endoscopic medial maxillectomy with preservation of inferior turbinate and nasolacrimal duct. Am J Rhinol Allergy 2012;26(5): 405-8.

4) Healy DY Jr, Chhabra N, Metson R, Holbrook EH, Gray ST. Surgical risk factors for recurrence of inverted papilloma. Laryngoscope 2016; 126(4):796-801.

5) Wormald PJ, Ooi E, van Hasselt CA, Nair S. Endoscopic removal of sinonasal inverted papilloma including endoscopic medial maxillectomy. Laryngoscope 2003;113(5):867-73.

6) Eloy P, Mardyla N, Bertrand B, Rombaux P. Endoscopic endonasal medial maxillectomy: Case series. Indian J Otolaryngol Head Neck Surg 2010;62(3):252-7.

7) Suzuki M, Nakamura Y, Yokota M, Ozaki S, Murakami S. Modified transnasal endoscopic medial maxillectomy through prelacrimal duct approach. Laryngoscope 2017;127(10):2205-9.

8) Lee HJ, Joo YH, Jeon SY, Kim SW. A case of removal of medial maxillary intraosseous hemangioma through an intranasal endoscopic prelacrimal recess approach. Korean J Otorhinolaryngol-Head Neck Surg 2015;58(12):870-3.

9) Zhou B, Han DM, Cui SJ, Huang Q, Wei YX, Liu HC, et al. Endoscopic nasal lateral wall dissection approach to maxillary sinus. Zhonghua Er Bi Yan Hou Tou Jing Wai Ke Za Zhi 2007:42(10):743-8.

10) Gao L, Zhou L, Dai Z, Huang $X$. The endoscopic prelacrimal recess approach to the pterygopalatine fossa and infratemporal fossa. $\mathrm{J}$ Craniofac Surg 2017;28(6):1589-93.

11) He S, Bakst RL, Guo T, Sun J. A combination of modified transnasal endoscopic maxillectomy via transnasal prelacrimal recess approach with or without radiotherapy for selected sinonasal malignancies. Eur Arch Otorhinolaryngol 2015;272(10):2933-8.

12) Yu QQ, Guan G, Zhang NK, Zhang XW, Jiang Y, Lian YY, et al. Intranasal endoscopic prelacrimal recess approach for maxillary sinus inverted papilloma. Eur Arch Otorhinolaryngol 2018;275(9): 2297-302.

13) Kim DY, Hong SL, Lee CH, Jin HR, Kang JM, Lee BJ, et al. Inverted papilloma of the nasal cavity and paranasal sinuses: A Korean multicenter study. Laryngoscope 2012;122(3):487-94.

14) Zhou B, Huang Q, Sun J, Li X, Zhang W, Cui S, et al. Resection of inverted papilloma of the maxillary sinus via a prelacrimal recess approach: A multicenter retrospective analysis of surgical efficacy. Am J Rhinol Allergy 2018;32(6):518-25. 